\begin{tabular}{rr} 
çağdaş & Yaratıcı Drama Dergisi 2016, 11(1), 89-104 \\
drama & www.yader.org \\
\hline
\end{tabular}

\title{
İlkokul 4. Sınıf Öğrencilerinin Amaç Belirleme Becerilerinin Geliştirilmesi için Yaratıcı Drama Yönteminin Kullanılması*
}

\author{
Barış Sarısoy ${ }^{1}$ \\ Şeyda Orhan ${ }^{2}$
}

\begin{tabular}{|c|c|c|}
\hline \multicolumn{2}{|c|}{ Makale Bilgisi } & $\ddot{\mathbf{O} z}$ \\
\hline \multicolumn{2}{|c|}{ DOI: 10.21612/yader.2016.006 } & $\begin{array}{l}\text { Araştırmanın amact, ilkokul 4. sınıf öğrencilerinin amaç belirleme becerilerini } \\
\text { gelistirmek icin varatıcı drama yöntemini kullanmaktır. Calısma, İstanbul ili }\end{array}$ \\
\hline \multicolumn{2}{|c|}{ Makale Geçmişi } & Beyoğlu ilçesi Milli Eğitim Müdürlüğüne bağll Okçu Musa Ilkokulu'nun 4-B \\
\hline Geliş tarihi & 22.05 .2015 & sınıfinda öğrenim gören 16 öğrencinin gönüllü katılımlarıyla gerçekleşmiştir. \\
\hline & 28.10 .2015 & $\begin{array}{l}\text { Araştırma deseni olarak karma yöntem seçilmiş, veriler nicel ve nitel veri toplama } \\
\text { yöntemleri ile toplanmıștır. Araștırmanın nicel bölümünde, çalıșmanın kazanımlarını }\end{array}$ \\
\hline Kabul & 12.03 .2016 & $\begin{array}{l}\text { sınayacak şekilde oluşturulan kazanım değerlendirme sınavı uzman görüşlerinden } \\
\text { yararlanılarak oluşturulmuş ve ön test - son test şeklinde uygulanmıştır. Kazanım }\end{array}$ \\
\hline \multicolumn{2}{|c|}{ Anahtar Sözcükler } & $\begin{array}{l}\text { değerlendirme sınavinın ön test ve son test sonuçları Wilcoxcon İşaretli Sıralar } \\
\text { Testi kullanılarak analiz edilmistir. Arastırmanın nitel bovutunda ise öğrenci }\end{array}$ \\
\hline \multicolumn{2}{|c|}{ Duygusal zeka } & ürünleri ve atölye sonlarında uygulanan ölçme-değerlendirme formları betimsel \\
\hline & analizle, genel değerlendirme atölyesinde yapılan odak grup görüşmesi ise içerik \\
\hline \multicolumn{2}{|c|}{$\begin{array}{l}\text { Amaç belirleme } \\
\text { Yaratıcı drama }\end{array}$} & $\begin{array}{l}\text { analizi ile değerlendirilmiștir. Araştırma kapsamında nicel ve nitel verilerin } \\
\text { değerlendirilmesi sonucunda: yaratıcı drama yöntemi ile olusturulan öğrenme }\end{array}$ \\
\hline \multicolumn{2}{|c|}{ Yaratıcı drama } & $\begin{array}{l}\text { degerlendirllmest sonucunda; yaratıcl drama yontemı ule oluşturulan ogrenme } \\
\text { yaşantısının, katılımcıların olumlu yönde amaç belirleme becerisini geliştirdiği } \\
\text { sonucuna ulaşlmıştır. }\end{array}$ \\
\hline \multicolumn{3}{|c|}{$\begin{array}{c}\text { Using Creative Drama Method to Develop Goal Setting Skills of } \\
\text { Primary School 4th Grade Students' }\end{array}$} \\
\hline \multicolumn{2}{|c|}{ Article Info } & Abstract \\
\hline \multicolumn{2}{|c|}{ DOI: $10.21612 /$ yader.2016.006 } & $\begin{array}{l}\text { The aim of the study is, to use creative drama methods to develop the skills of } \\
\text { goal setting in 4th grade elementary school students. The study was made with the }\end{array}$ \\
\hline \multicolumn{2}{|c|}{ Article History } & voluntarily participation of 16 students who studying in 4-B class in Okçu Musa \\
\hline Received & 22.05 .2015 & $\begin{array}{l}\text { Elementary School through the Beyoglu district of Istanbul, under the National } \\
\text { Ministry of Education. As for research design mixed method was selected; the data }\end{array}$ \\
\hline Revised & 28.10 .2015 & were collected through qualitative and quantitative data collection methods. In the \\
\hline Accepted & 12.03.2016 & $\begin{array}{l}\text { qualitative part of the research, the gain assessment exam was constructed to test } \\
\text { the gains of the study by using the opinions experts and it was implemented as a } \\
\text { pretest-posttest. The results of the gain assessment exams pretest and posttest was }\end{array}$ \\
\hline \multicolumn{2}{|l|}{ Keywords } & analyzed through using Wilcoxon signed ranks test. In the qualitative dimension of \\
\hline \multicolumn{2}{|c|}{ Emotional intelligence } & the research the products of students and assessment-evaluation forms applied at \\
\hline \multicolumn{2}{|c|}{ Self-management } & ind of workshops through descriptive analysis, however; focus group interviews \\
\hline \multicolumn{2}{|c|}{ Goal setting } & $\begin{array}{l}\text { held on the overall assessment workshop were evaluated through the content } \\
\text { analysis. Within the scope of the study, according to the evaluation of quantitative }\end{array}$ \\
\hline \multicolumn{2}{|c|}{ Creative drama } & $\begin{array}{l}\text { and qualitative data results; it has been reached that learning experiences of } \\
\text { participants learned by the method of creative drama developed a positive effect on } \\
\text { goal setting skill. }\end{array}$ \\
\hline
\end{tabular}

Bu çalışma MEB Özel Doğaç Yaratıcı Drama Liderliği Projesi’nden geliştirilmiştir.

2 Eğitimde Program Geliștirme Sorumlusu, E-posta: barissrsy@gmail.com

3 Sınıf Öğretmeni-Yaratıcı Drama Lideri, Ankara Üniversitesi Vakıf Okulları, E-posta: seydaoorhan@gmail.com 


\section{Giriş}

Eğitim kurumlarının en önemli amaçlarından biri, yaşam becerileri gelişmiş, ne istediğini bilen, gerçek yaşamda karşılaştığı sorunlar karşısında duygularını yöneten, kendini tanıyan ve yaşadığ1 topluma karşı sorumlu bireyler yetiştirmektir. Bireyler okullarda yeni yaşantılar geçirerek hayatı öğrenme olanăğ bulurlar. Eğitim yaşantıları ile yaşam becerileri edinen ve kendisiyle ilgili çeşitli farkındalıklar kazanabilen birey, hayata atıldığında kendini yaşamın getirilerine karşı hazır hissetmeye başlar. Bu da bireyin kendine olan güvenini arttırarak, başarılı ve istediği yönde mutlu bir yaşam sürmesine olanak sağlar.

Çocuklar okul öncesi dönemden sonra ilkokulda, yaşamın getirilerini ve çizgilerini daha yoğun bir şekilde tanımaya başlar. Bu dönemde en önemli nokta, çocuğun eğitim süreci ile gerçek yaşamın örtüşmesidir. Eğer çocuğa ilkokul düzeyinde öğrendikleri ile gerçek yaşamı arasında bağlantı kurma fırsatı verilmezse çocuk bu dönemde edindiği bilgi ve becerileri gerçek yaşamında işlevsel hale getiremeyebilir. Bu nedenle çocukların ilkokul dönemindeki eğitim yaşantıları, kendi yaşam serüvenlerinde hep ihtiyaç duyacakları becerileri kazanmaları açısından çok önemlidir. Bu açıdan bakıldığında ilköğretim 1., 2. ve 3. sınıflarda yer alan Hayat Bilgisi dersi çocukların kendilerini, yaşadıkları toplumu ve dünyayı tanımaları için tasarlanmış ve 1924, 1936, 1948, 1968, 1998, 2005 yıllarında oluşturulan eğitim programlarında yerini almıştır ( Karaca ve Ocak, 2011 ).

Geleneksel eğitim anlayışından çağdaş eğitim anlayışına geçilmesi ile birlikte çocukların sadece akademik anlamda başarısının yeterli olmadığı, sosyal ve duygusal anlamda da çeşitli beceriler kazanmalarının gerekliliği ön plana çıkmıştır. Bu doğrultuda 2004-2005 eğitim-öğretim yılında yeniden düzenlenen ilköğretim Hayat Bilgisi Dersi Öğretim Programı'nda öğrencilerde oluşturulması gereken becerilere daha geniş bir kapsam ayrılmıştır. Bu öğretim programını önceki programlardan ayıran en önemli özelliklerinden biri de öğretim sonucunda öğrencilerde geliştirilecek becerilerin neler olduğunun açık bir şekilde tanımlanması ve sınıflandırılmasıdır (Kabapınar, 2009). İlköğretim Hayat Bilgisi Dersi Öğretim Programı'ndaki bu beceriler programda ayrıntılı olarak alt becerilerle sunulmuştur. Bu alt becerilerin bir kısmı davranışlar olarak ifade edilmiştir.

İlköğretim Hayat Bilgisi Dersi Öğretim Programı'nda verilen bu beceriler ayrıntılı bir şekilde incelendiğinde, çoğu becerinin ön koşul becerisi olarak öz yönetim becerisi göze çarpmaktadır, çünkü öz yönetim becerisi bireyin kişisel gelişim ve yaşam boyu öğrenme yolculuğunda, kendini düzenlemesi ve denetlemesini sağlayan bir rol üstlenmektedir (Goleman, 2011). Öz yönetim ilk olarak, Mayer ve Peter Salovey tarafindan geliştirilen duygusal zekâ kavramı ile birlikte ortaya çıkmıştır (Salovey ve Mayer, 1990). Daha sonra duygusal zekânın öz yönetim gibi alt alanları, 1995 yılında Daniel Goleman'ın "Duygusal Zekâ" kitabında daha detaylı ele alınıp dünya literatüründe yerini almıştır. Boyatzis (2002)' in tanımı ile duygusal zekânın en önemli alt alanlarınındın biri olan öz yönetim, "Kişinin kendi duygularını anlaması, hedeflerine ulaşmak için gereksindiği motivasyondan doğar. Öz yönetim ne hissettiğini bilmek ve bu hisleri idare etmektir. Öz yönetime sahip birey, coşku ve zorluğu yenme gibi olumlu duyguları idare eder, aynı zamanda hüsran ve hiddet gibi olumsuz duyguları da yönetebilir” (Boyatzis, 2002, s.56). Öz yönetim bir diğer anlamda bireyin içsel kontrolünü eline alması ve kendini hedefleri ve amaçları yönünde, duygusal boyutta düzenlemesidir. Öz yönetim becerisi yüksek olan bireyin en önemli yetilerinden biri, amaçlarına ulaşma konusunda kendisini fiziksel ve psikolojik açıdan düzenleyebilmesi ve yönetebilmesidir.

Amaçları gerçekleştirmek, bireyi psikolojik bir doyuma ulaştırır. Yaşamda mutlu olmak için sadece fizyolojik ihtiyaçların yerine gelmesi yeterli değildir. Bireyin yaşam boyu sürecek gerçek 
mutluluğa ulaşabilmesi ancak ve ancak psikolojik ihtiyaçlarının yerine getirilmesiyle sağlanır. Herhangi bir amacı olmayan birey yaşamda yolunu kaybetmiş bir yolcu gibidir. Bu yolda nerede olduğunu, nereye gittiğini veya neler olacağını bilemez. Dolayısıyla bireylerin yaşam yolunda nereye gittiğini bilmesi ve amaçlarına ulaşırken karışılabileceği tüm zorluklara karşı kendini hazırlaması gerekir. Bu da ancak bireyin erken bir dönemde amaçlarının yaşam sürecindeki önemi konusunda kazandığ 1 farkındalıklarla ve amaçlarına ulaşabilmek için edindiği duygusal zekâ becerileri ile gerçekleşir.

Duygusal zekâ; doğuştan gelen, sonradan kazanılan ve geliştirilen becerilerden oluşur. $\mathrm{Bu}$ da bireyin duygusal zekâsının eğitim yaşantıları yoluyla geliştirilebileceği anlamına gelir. Jeager'ın 2003 yılında yaptığı araştırmada deney ve kontrol gruplarından, deney grubuna duygusal zekâ odaklı bir eğitim programı uygulamış ve duygusal zekâ-öğrenme arasındaki ilişkiyi saptamak istemiştir. Araştırmanın en önemli bulgularından biri; duygusal zekânın okul ortamında eğitim yolu ile geliştirilebileceği olmuştur (akt. Cingisiz ve Murat, 2010). Bu araştırmada da duygusal zekânın, bireyin bu becerilerini geliştirmeye yönelik olarak programlanmış bir eğitim yaşantısı ile geliştirebileceğini somut olarak göstermektedir.

Daniel Goleman (2011, s.8)'e göre “İlköğretimin ilk y1llarında öğrencilerin duygularını tanıyıp, doğru adlandırabilmeleri ve bu duyguların kendilerini nasıl harekete geçirdiğini tanımlayabilmeleri gerekir." Duygusal zekâ becerisi ve onun alt becerilerinin geliştirilebilir olması, Goleman'ın da dediği gibi ilköğretim dönemi gibi erken dönemlerde çocuklarda geliştirilmesinin gerekliliğini ortaya koymaktadır.

Duygusal zekâ kavramının ortaya çıkışını izleyen on yılda, eğitimde duygusal öğrenime önem verilmiş ve buna yönelik eğitim programları oluşturulmuştur (Mayer ve Cobb, 2000; Salovey ve Sluyter, 1997). Bu doğrultuda Schilling' in 1996'da "50 Activities for Teaching Emotional Intelligence: Elemantry I” adı altında yayımladığı kaynak kitap ilköğretim öğrencileri için duygusal zekâ programları geliştirmesinde önemli denilebilecek bir adım oluşturmuştur (Mayer, Salovey ve Caruso, 2002). Daha sonra bazı okullarda düzenlenen bu duygusal zekâ gelişim programları "Social and Emotional Learning (SEL)" adı altında bir araya toplanmıştır ve sistematik bir şekilde okul programlarında yerini almaya başlamıştır (Cohen, 1999). Bunun dışında birçok ülkede uygulanan "Self Science" (öz bilim) dersleri, en çok bilinen duygusal zekâ gelişimi için oluşturulan eğitim programlarından birisidir.

Dünya literatüründe ve alan kapsamında duygusal zekânın alt alanı olarak geçen öz yönetim becerileri ve alt alanları, ilk olarak 2005 yılında yenilenen Hayat Bilgisi Öğretim Programı'nda yerini almış ve ders içi kazanımlarla ilişkilendirilerek öğrencilere kazandırılması ön görülmüştür. Uluslararası bağlamda yapılan çalışmalar incelendiğinde, duygusal zekâ ve öz yönetim gibi alt alan becerilerinin gelişimine, en az öğrencinin akademik gelişimi kadar önem verilmiş ve bu becerilerin geliştirilmesi için farklı eğitim programları geliştirilmiştir. Eğitim kalitesi yüksek olan ülkelerin duygusal öğrenime verdiği öneme bakıldığında, ülkemizde öz yönetim becerileri ve onun alt alanlarının gelişimine gerektiği kadar önem verilmediği ortaya çıkmaktadır. Ayrıca 2005'te Eğitim Programları ve Öğretim Profesörler Kurulu Yeni İlköğretim Programını Değerlendirme Toplantısı Sonuç Bildirisi’nde de, yenilenen Hayat Bilgisi Öğretim Programı'nda verilen bu beceri alanlarında çeşitli sorunlar tespit edilmiştir (EPÖ Prof. Kurulu, 2005). Fakat genel anlamda, özellikle programda eksikliği düşünülen alandaki sorun tespiti derinlemesine ele alınamamış ve uygulamadaki eksiklik giderilememiştir. 
Hayat Bilgisi Dersi Öğretim Programı'nda öz yönetim ve diğer becerilerin açıklamalarına bakıldığında bu becerilerin kazandırılmasında bir belirsizlik söz konusudur. Bu açıklamalarda verilen becerilerin öğrencilerde oluşmasında kesin ve net bir yol bilinmediği ifade edilmiştir (MEB, 2009). Öğrencilerin kendi yaşamları bağlamında en az akademik beceriler kadar önemli, hatta kimi zaman daha da önemli olan bu becerilerin, üç yıllık hayat bilgisi dersi sürecine yayılmış kazanımlarla ilişkilendirilerek öğrencide oluşturulabileceği ön görülmüştür. Fakat becerilerin alan açıklamasında verilen hedeflere ve üç yıllık programdaki ilişkilendirilmiş kazanımlarına bakıldığında; kazanımların bazı noktalarda verilen hedeflerle örtüşmediği, verilen hedeflere göre kazanımların yetersiz kaldığı düşünülmektedir. Genel olarak bakıldığında ise bu becerilerden en az kazanımla desteklenen alanın; öz yönetim becerileri, amaç belirleme alt alanı olduğu göze çarpmaktadır. Bu doğrultuda öz yönetim becerileri amaç belirleme alt alanının, üçüncü sınıfı tamamlamış bir öğrencide, programda verilen biçimiyle, nitelikli bir şekilde gelişmeyeceği ve öğrencinin sosyal yaşamında bu beceriyi hayatına geçiremeyeceği düşünülmektedir. Ayrıca bu varsayımı doğrulamak için araştırma öncesinde yapılan program değerlendirme çalışmasında, program geliştirme uzmanlarının ve sınıf öğretmenlerinin görüşlerine başvurulmuş ve sonuç olarak başta öğretim programı olmak üzere çeşitli sebeplerden dolayı amaç belirleme becerilerin öğrencilerde oluşmadığı sonucuna ulaşılmıştır.

İlköğretim Hayat Bilgisi Öğretim Programı’nda yer alan açıklamalara bakıldığında, program kapsamında verilen becerilerin kazandırılması için etkili öğrenme yaşantısı oluşturulmasının gerekliliği ortaya çıkmaktadır. Oluşturulacak öğrenme yaşantısında çocuğun Hayat Bilgisi Öğretim Programı'nda bulunan bu becerileri, en iyi şekilde yaşamıyla ilişkilendirip kurgusal bir gerçeklik içerisinde deneyimlemesi ve edindiği becerileri bizzat kullanarak önemini fark etmesini sağlayacak bir yöntem seçilmesi gerekmektedir. Bu yönde bakıldığında yaşantı odaklı bir yöntem olan yaratıcı drama, oluşturulacak olan öğretim tasarımının, öğrenme-öğretme süreçleri bölümde işe koşulacak en etkili yöntemlerden biri olarak göze çapmaktadır.

Eğitimde kullanılan etkili bir yöntem olarak yaratıcı drama sürecinde öğrenci tarafindan içselleştirilen bilgi, diştan gelen bir yönlendirme olmadan, içsel güdülerle birlikte ortaya çıkar ve öğrencinin bu bilgiyi yaşam sürecinde aktif olarak kullanması ile anlam kazanır. Bununla beraber birey gerçek yaşamda bilgiyi eyleme geçirmeye ve öğrenmeyi yaşantıya dökmeye başlar. Çünkü yaratıcı drama sürecinde kurgusal gerçeklik aracılığıyla bilginin işlevselliğini ve kullanım biçimini deneyimleyen veya gözlemleyen öğrenci tarafından bilgi içselleştirilir. Adıgüzel (2006)'in belirttiği gibi drama süreçleri gerçekmiş gibi yaşanır çünkü drama gerçek hayatta karşılaştığımız kuralların aynısını kullanır. Drama, yaşamı oynama ve uygulama aracıdır.

Yaratıcı drama, öğrencilerin yaparak ve yaşayarak öğrenmelerine olanak sağlar. Yaparak ve yaşayarak öğrenen çocukta öğrenilen davranış somutlaşır, öğrenci fark ettiği olguyu nerede ve nasıl kullanacağını canlandırmalar yoluyla yaşantıya dökerek bir anlamda soyut bir olguya anlam yüklemiş olur. Böylece yaşantılara dayalı bir öğrenme süreci gerçekleşmiş olur.

Üstündağ (1994)'a göre yaratıcı drama, yaşam durumlarını oyunda var olan "kurallar içerisindeki özgürlük" ögesini kullanarak yaratıcı süreçlere dönüştürmek yoluyla; katılımcılara kendini keşfetme, tanıma, başkalarını tanıma, kendini başkalarının yerine koyabilme olanağı veren bir öğretim yöntemi ve bir sanat eğitim alanıdır. Yaratıcı drama süreci içerisinde kişi, sürecin başından sonuna kadar bir yaratım içerisindedir. Birey yaşantısı yoluyla cebinde biriktirdiği deneyimleri süreç 
içerisindeki yaratımları ile ortaya çıkarır ve kendine bir dış göz olup yaratımıyla kendini keşfetme olanağına sahip olur. Ayrıca yaratıcı drama belirli bir katılımcı grubu ile yapılan bir disiplin özelliğine sahip olduğu için kişi, kendini keşfetmenin yanında başkalarının da yaşamlarını keşfederek yeni yaşantılar gözlemler. Kendisini, çevresini tanıyan ve öz farkındalığı gelişen bireyin çeşitli yaşam becerileri de bu doğrultuda gelişmiş olur.

"Yaratıcı drama sürecinde bir arayış, merak ve bulma isteği söz konusudur. Bu istek içerisinde yer yer yarışma ögesinin de olduğu gerilimler yaşanır ki bu tüm yaratıcı drama katılımcılarına bir haz yaşatır. Bu haz oyunda olan eğlenceden, özgürce yaratmadan, öyleymiş gibi yapma özelliklerinden kaynaklanır" (Adıgüzel 2012, s.67). Çağdaş eğitim anlayışının temel özelliklerinden biri öğrencinin öğrenmeden haz almasını sağlayıp istekli ve aktif olarak sürece katılımını desteklemektir. Özellikle ilköğretim dönemindeki çocuk, oyunsu süreçlerden büyük haz alır ve bu süreçlere istekle katılır. Locke'un "Çocuklara oynuyormuş duygusu vererilerek öğretilebilir. Çocuk kendi içinden gelenleri seve seve yapar, dıştan baskıyla yaptırılanlardan çabuk usanır." ifadesi bu verileni destekleyecek niteliktedir (Bozdoğan, 2006).

Yaratıcı drama, çocukların duygularını, düşüncelerini ve davranışlarını değiştirebilen, katılım ve iletişimin güçlü bir aracıdır. Ayrıca etkileşimi arttırarak algıyı keskinleştirir ve bireyin kendisini ifade etmesini kolaylaştırdığ gibi düşünsel ve duyuşsal gelişimine de katkıda bulunur (Somers, 1994). Yaratıcı drama, Sommers'ın da belirttiği gibi özellikle öğrencilerin duyuşsal gelişimlerinde önemli bir yer tutar. Bu açıdan bakıldığında yaratıcı drama, duyuşsal kazanımların ağırlıklı olduğu öğrenme süreçlerinde işe koşulacak en etkili yöntemlerden biridir.

Yukarıda verilenler incelendiğinde, uzmanlar yaratıcı drama çalışmalarının amaçlarını bireyde sağladığı gelişimler açısından tanımlamışlardır. Bu amaçlar genel olarak; çocukların esnek ve yaratıcı bir şekilde düşünme, sabırlı olma, olumlu benlik tasarımı, öz-yönetim, kendine ve başkalarına güven duyma, saygı duyma, kendinin ve diğerlerinin duygularını düşüncelerini keşfetme, çevresinin farkında olma, kendisinin ve diğerlerinin davranışlarının nedenlerini anlama, sorumluluk alma, kurallara uyma, sosyal sorunlarla baş etme gibi sosyal becerileri geliştirmektir (Peter, 2003, s.26; Hendy ve Toon, 2001, s.56; Heining, 1993, s.10; Güleç, 2005, s.867; Freeman ve diğ., 2003, s.131; Brown ve Pleydell, 1999, s.127; Eratay, 2005, s.83; Cömertpay, 2006, s.50; Gönenve Uyar Dalkılıç, 2002, s.31'den Akt. Ceylan, 2009) şeklinde toparlanabilir.

Alan yazında var olan yaratıcı drama tanımları ve eğitimde yaratıcı dramanın bir yöntem olarak etkinliği konusundaki görüşler incelediğinde, yaratıcı drama yönteminin öz yönetim becerileri, amaç belirleme alt alan becerisini geliştirmek için kullanılacak en etkili yöntemlerden biri olduğu düşünülmektedir.

\section{Çalışmanın Amacı}

Bu çalışmada amaç; amaç belirleme becerisini kazanmamış olduğu düşünülen ilkokul 4.sınıf öğrencilerinin amaç belirleme becerilerini geliştirmek için yaratıcı drama yöntemini kullanmaktır. $\mathrm{Bu}$ amaç doğrultusunda oluşturulan öğrenme yaşantısı sonucunda öğrencilerin beceri gelişimleri nitel ve nicel verilere göre değerlendirilecektir. 


\section{Yöntem}

\section{Araştırma Deseni}

Araştırmada karma araştırma deseni kullanılmıştır. Karma çalışmalar nitel ve nicel veri toplama tekniklerinin aynı anda veya birbirinin devamı şeklinde uygulanması şeklinde oluşur (Balcı, 2011). Çalışmanın nicel boyutunda yarı deneysel desen uygulaması kullanılmıştır. Nicel araştırmada yarı deneysel desende yapılan işlemin etkisi tek bir grup üzerinde yapılan çalışma ile test edilir (Can, 2013). Bu doğrultuda çalışma grubu öğrencilerine proje uygulanmadan önce ön-test ve proje uygulandıktan sonra değişimi gözlemlemek için son-test çalışması uygulanmıştır. Çalışmanın nitel bölümünde durum araştırma deseni kullanılmıştır. Nitel araştırmada durum araştırma deseni, var olan veya oluşmakta olan bir durumun derinlemesine incelenmesine olanak sağlar (Glense, 2011). Veri toplama yöntemi olarak öğrencilerle proje sonunda yapılan odak grup görüşmeler, her atölyenin sonunda kazanımlara yönelik olarak uygulanan ölçme değerlendirme formları ve öğrenci ürünleri dokümantasyon inceleme teknikleri kullanılarak toplanmıştır.

\section{Çalışmanın Katılımcıları}

Bu çalışmaya İstanbul ilinin Beyoğlu ilçesinde bulunan, MEB Okçu Musa İlkokulu'nun 4-B sınıfindaki öğrenciler katılmıştır. Sınıf 5’i (\%69) kız, 11’i (\%31) erkek olmak üzere 16 öğrenciden oluşmaktadır. Öğrencilerin tamamı çalışmaya gönüllü olarak katılma isteğinde bulunmuştur. Ayrıca çalışmaya katılan grubun yaratıcı drama yaşantısı bulunmaktadır. Çalışmada 4. sınıf öğrencilerinin seçilmesinin nedeni ise; yapılan program değerlendirme sonucunda üç senelik hayat bilgisi programının ögrencilerde amaç belirleme becerisini nitelikli olarak geliştirmemiş olmasıdır.

\section{Verilerin Toplanması}

Çalışmanın nicel veri toplama kısmında, öğrencilerin amaç belirleme becerisini geliştirmek için oluşturulan projenin hedeflediği kazanımların öğrencilerde oluşup oluşmadığını ortaya koymak için ön-test, son-test uygulaması yapılmıştır. Ön-test son-test uygulaması, çalışma kapsamında oluşturulan kazanımlardan on kritik kazanım belirlenerek oluşturulmuştur. Belirlenen kritik kazanımları değerlendirecek on tane açık uçlu soru, senaryo temelli olarak oluşturulmuştur. Oluşturulan sınav atölyeler başlamadan uygulanıp sonrasında herhangi bir değişiklik yapılmadan atölyelerin sonunda da uygulanmıştır. Bu sınav oluşturulurken, üç sınıf öğretmeni, iki ölçme değerlendirme uzmanı görüşlerine başvurulmuş ve incelemeler sonucunda gelen dönütler doğrultusunda gerekli düzenlemeler yapılıp uygulamaya hazır hale getirilmiştir.

Çalışmanın nitel veri toplama kısmında ise, uygulanan yaratıcı drama atölyelerinin değerlendirme kısımlarında yapılan ölçme değerlendirme çalışmaları ve formları, öğrencilerin amaç belirleme becerisi konusundaki gelişimlerini değerlendirilebilmesi için veri olarak toplanmıştır. Bunun yanında tüm atölyelerin sonunda öğrencilere bu çalışmadan sonra amaçlarını belirlerken ve amaçlarına ulaşma sürecinde nelere dikkat edecekleri konusunda odak grup görüşmesi yapılmıştır.

\section{Verilerin Analizi}

Katılımcıların başarı sınavına vermiş oldukları açık uçlu yanıtlar dereceli puanlama anahtarı kullanılarak puanlandırılmıştır. Oluşturulan kazanım değerlendirme sınavındaki katılımeı başarı puanı ile ilgili veriler SPSS 16.0 paket programının Wilcoxon İşaretli Sıralar Testi kullanılarak analiz 
edilmiştir. Analiz sonucunda kritik kazanımlar belirlenerek oluşturulan sınav sonuçlarının ön-test ve son-test uygulamasında anlamlı farklılıklar bulunup bulunmadığı incelenmiştir. Araştırmanın nitel bölümünde ise veriler betimsel analiz ve içerik analizi yöntemleri ile incelenmiştir. Betimsel analizde daha önceden belirlenen temalar doğrultusunda veriler analiz edilir. İçerik analizinde ise verilerin kendi içerisinde ortaya çıkardığı temalar kategorileştirilerek yorumlanır (Yıldırım ve Şimşek, 2011).

\section{Nicel Verilerin Analizi}

Bu bölümde çalışmanın kritik kazanımları doğrultusunda oluşturulan kazanım değerlendirme sınavının ön-test ve son-test uygulamaları sonucunda, toplam sınav puanlarının Wilcoxon İşaretli Sıralar Testi’ne göre istatistiksel analizleri incelenmiş ve yorumlanmıştır.

\section{Nitel Verilerin Analizi}

Öğrencilerin amaç belirleme becerilerini geliştirmeye yönelik olarak oluşturulan yaratıcı drama atölyelerinin sonunda yapılan değerlendirme etkinliklerinde kullanılan formlar ve ortaya çıkan öğrenci ürünlerinin betimsel analizi yapılmıştır. Veriler ölçme değerlendirme formlarının uygulandıkları atölyelerin başlığı altında bir araya getirilerek incelenmiştir. Uygulanan her formda, o atölyenin kazanımına ulaşıldığını gösteren veriler ve öğrencilerin sözel ifadelerinden yapılan doğrudan alıntılarla desteklenmiştir.

\section{Bulgular ve Yorum}

\begin{tabular}{llllll}
\hline Sontest - Öntest & N & Sıralama Ortalaması & Sıra Toplamı & Z & P \\
\hline Negatif Değişim & 0 & 0 & 0 & 3,541 & 0,0001 \\
Pozitif Değişim & 16 & 8,5 & 136 & & \\
Eşit Kalan & 0 & & & & \\
\hline
\end{tabular}

Kazanım Değerlendirme Sınavları doğrultusunda öğrencilerin amaç belirleme düzeyindeki gelişmeleri belirlemeye yönelik olarak yapılan analiz sonuçları Tablo 1'de gösterilmiştir.

Tablo 1. Kazanım Değerlendirme Sinavlarının Wilcoxon İşaretli Siralar Testi Ön test-Son test Sonuçlart

$\mathrm{N}=16 \mathrm{p}<0.01$

Kazanım değerlendirme sınavında katılımcıların aldığı toplam puanlar bazında ön test-son test sonuçları arasında anlamlı fark bulunmuştur $(\mathrm{p}<0.01)$. Katılımcıların ön testten aldıkları toplam puanın ortalaması 3,125 iken son testte aldıkları puanların ortalaması 16,875'e yükselmiştir. Ayrıca kazanım değerlendirme sınavının toplam öntest puanlarında \%16 başarı sağlanmışken, bu başarı puanı sontestte \%84' e çıkmış ve yaklaşık olarak tam puanlar üzerinden \% 68 artış olmuştur. Ortaya çıkan sonuçlar incelendiğinde, öğrencilerin amaç belirleme becerileri konusunda olumlu düzeyde farkındalık kazandıkları belirlenmiştir.

\section{Nitel Verilere İlişkin Bulgular}

Bu bölümde, öğrencilerin amaç belirleme becerilerini geliştirmeye yönelik olarak oluşturulan yaratıcı drama atölyelerinin sonunda yapılan değerlendirme etkinliklerinde kullanılan formlar ve ortaya çıkan öğrenci ürünlere ilişkin bulgular sunulmuştur. 


\section{Amaçlar ve Hayallere Verilen Önem}

İlk olarak “Amaçlar ve Hayaller” atölyesinin sonunda yapılan Öz-Değerlendirme formunda öğrencilerin atölyeden genel olarak amaçlar ve hayaller konusunda öğrendiklerini ve bu atölyeden sonra amaçlar ve hayaller konusunda nelere dikkat edeceklerini yazmaları istenmiştir. Öğrencilerin “Öz-Değerlendirme Formu”nda belirttikleri cevaplara bakıldığında:

"Bu etkinlikte amaçlar ve hayaller konusunda öğrendiğim şeyler hayallerine inanmak, vazgeçmemek, çalışmak.", "Bundan sonra çok çalışırım öğrenirim sonra amacıma ulaşırım”, "Çok çalışarak bir amacı yerine getirebileceğimi öğrendim..."

Öğrencilerin çoğu Öz-Değerlendirme Formlarına belirlenen hayaller konusunda "çalışmanın önemine" vurgu yapmışlardır. Bunun yanında bazı öğrenciler bundan sonra amaçlarını ve hayaller konusunda nelere dikkat etmeleri gerektiği ifadesine, atölyede işlenen Lupi karakterini örnek alacaklarını belirtmişlerdir.

"Lupi gibi amacıma ulaşmayı, daha çok çalışmayı ve onu başarmalıyım.”, "Lupinin yaptı̆̆ gibi çok çalışmak, vazgeçmemek”

Öğrencilerin bu ifadelerine bakıldığında, amaçlar konusunda çalışmanın önemini ve asla vazgeçmemenin gerekliliğini fark etikleri ortaya çıkmaktadır.

\section{Yaşantısı ile Uyumlu Amaçlar Seçme}

Öğrencilere amaçlar konusunda bir seçim yapmanın gerekliği ile ilgili olarak yapılan atölyenin sonucunda "Karakter Değerlendirme Formu" dağıtılmış ve atölyenin içeriğinde bulunan Lupi karakterini değerlendirebilecekleri sorular forma eklenmiştir. Öğrenciler Lupi karakterinin olumlu ve olumsuz özelliklerini vurgulayarak ona çeşitli önerilerde bulunmuşlardır. Genel olarak bakıldığında öğrencilerinin büyük çoğunluğu Lupi’nin olumlu özelliği olarak “Amaçları için çok çalışmasını ve hayaller kurmasını" ifade etmişlerdir.

"Lupi’nin olumlu bulduğum özelliği hayaller kurması”, "Çok çalışması”, "Çok iddalı olması", "Okyanusun en hizlist olmak istemesi hayali"

Yukarıdaki ifadelere bakıldığında öğrencilerin Lupi’nin hayaller kurmasını ve bu hayalleri için çalışması özelliğini olumlu bulduklarını belirtmişlerdir. Bunun yanında ise bazı öğrenciler hızlı koşması, köpek balı̆̆ını geçmek gibi kapsam ile ilgili olmayan ifadelerde bulunmuştur. Öğrenciler Karakter Değerlendirme Formu'nun diğer kısımlarında Lupi'nin olumsuz özelliklerine, kendi yaşantısına uygun amaçlar belirleyip belirlemediğine, yapabildiklerini ve yapamadıklarını belirleyip belirlemediğine değinmişlerdir.

"Uçmak istiyor bu ona göre bir hayal değil", "Bence uçma hayali ona uygun bir hayal değil", "Lupi amaç belirlerken yapabildiklerine ve yapamadıklarına karar vermemiştir", Mesela yapabildikleri okyanusun en hızlısı olmak, köpek balığını geçmek. Yapamadıkları uçmak..."

Genel olarak verilen yanıtlara bakıldığında öğrencilerin amaç belirleme konusunda, yaşantılarına uyumlu seçim yapmanın gerektiğini kavradıkları görülmektedir.

\section{Amaçlar Arasından Bir Seçim Yapmanın Gerekliliği}

Öğrenciler bu atölyede, onlara yaşıtları olan başka bir öğrenciden gelen mektuba yanıt yazmak için “Kağan’a Öneri Mektubu” formunu kullanmışlardır. Öğrencilerin yazdıkları mektupların çoğunda Kağan’a öneri olarak amaçları arasından bir seçim yapması gerektiğini vurgulamışlardır. 
"Bence hepsini yapamazsin benim tavsiyem resim ama sen bilirsin..."

"Biz ikimiz aynı sinıfa gidiyoruz. Ben futbolcu olmak isterim ve 1 şey yapman gerekir.”

"Bence sen en iyi yapacă̆ın bir tanesini yapabilirsin çünkü birden fazlası sana çok fazla gelir. O yüzden çok iyi yapabileceğin şeyi seç bence Kağan.”

"Bence bu işlerden en iyi olduğun işi seç ve ya arkadaşlarına sor ya da sevdiğini seç"

Yukarıdaki ifadelere bakıldığında, öğrenciler genel olarak Kağan'ın bir tane amaç belirmesi gerektiğini ifade etmiş, ayrıca diğer atölyelerin konusu olan yaşantısına uyumlu amaçlar seçme konusunda da tavsiyelerde bulunmuşlardır. Bu da öğrencilerin amaçlar arasından bir seçim yapmanın gerekliliği kazanımına ulaştıklarını ortaya koymaktadır.

\section{Amaçlara Ulaşmak için Kendini Geliştirme}

$\mathrm{Bu}$ atölyenin sonunda öğrencilere "Kağan'1 tiyatro çalışmaları için değerlendirecek jürinin yerinde olsaydınız nasıl cevap verirdiniz?” sorusu yöneltimiştir. Öğrencilerin çoğunluğu Kağan'ın istekli ve çalışkan olmasından dolayı onu tiyatro çalışmalarına kabul edeceklerini belirterek kendini geliştirmeye istekli olmasını olumlu bulduklarını ifade etmişlerdir.

“Olumlu karşılardım çünkü istekliydi.", "Çok isterdim çünkü Kağan gelişmek istiyor."Çok çalışması ve gelişmesi”

Öğrencilerin açık uçlu sorulara verdikleri yukarıdaki yanıtlara bakıldığında, amaçlara ulaşmak için insanın kendini geliştirmesi konusunda farkındalık kazandıkları görülmektedir.

\section{Amaçların Somutlaştırılması}

Öğrenciler amaçlarını somutlaştırma ile ilgili olan atölyenin değerlendirme aşamasında bir bilim insanı olarak amaçlar belirlemiş ve bu amaçları görselleştirmişlerdir. $\mathrm{Bu}$ veriler incelendiğinde, öğrenciler belirledikleri amaçlara uygun görseller oluşturmuşlar ve bu görsellerin nasıl bir amaca hizmet ettiğini açıklamışlardır.

\section{Amaçlara Ulaşma Yollarını Planlama}

Öğrenciler amaçlara ulaşma yollarını planlama ile ilgili atölyenin sonunda, canlandırma aşamasında oluşturdukları ve yazılı olarak sonuca ulaştırdıkları durumu değerlendirmek için cümle tamamlama sorusundan oluşan bir form kullanmışlardır.

"Oluşan durumda belirlenen amaçta planlama yapılmadığından" seçeneğini işaretleyen grup bu durumla ilgili olarak;

"Planlı davranmamız gerekirdi. Kayığımız çok su geçirmemeli ve sağlam olmalı. Yanımıza keskin taş almalıydık ama almadık. Can yeleklerimiz de yoktu."

Denize açıldığımızda aç ve susuz kaldık. Gemimiz battı ve bir adaya gittik. Kurtulmak için plan yapsaydık böyle olmazdl."

"Planlı davranmalıyız" seçiğini işaretleyen gruplar ise;

"Adada mahsur kaldık, kimse bize yardım etmedi. Planlamamız1 yaptıktan sonra harekete geçtik bu sayede adadan kurtulmayı başardık."

"Eve döndük ve olumlu bir sonuç ortaya çıtk.." 
Yukarıda verilen ifadelere bakıldığında; öğrenciler amaçlara ulaşmak için planlama yapılmayan ve yapılan iki durumun sonuçlarını değerlendirmişler ve planlama yapıldığında olumlu sonuçlarla, yapılmadığında ise olumsuz sonuçlarla karşılaşılabilineceğini ifade etmişlerdir. Bu açıdan bakıldığında öğrencilerin amaçlara ulaşmada plan yapılması gerektiği konusunda farkındalık kazandıkları ortaya çıkmaktadır.

\section{Amaçlara Ulaşmadaki Zorluklar ve Çözümleri}

Amaçlara ulaşmadaki zorluklar ve çözüm yolları üretme ile ilgili olan atölyenin sonunda öğrencilerden bir amaç durumu belirlemeleri, bu amaca ulaşmada karşılarına çıkabilecek bir sorun ve bu soruna yönelik çözüm yolları üretmeleri istenmiştir. Öğrenciler grup çalışmaları doğrultusunda bu ürünleri oluşturmuşlardır. Oluşturulan ürünler diğer gruplara verilen "Akran Değerlendirme Formu" ile değerlendirilmiştir. Öğrenciler de görüldüğü gibi akran değerlendirme formunda diğer arkadaşlarının gerçek yaşama uygun bir amaç belirlediklerini ve bu amaca uygun bir sorun örneği yazdıklarını belirtmişlerdir. Ayrıca gruplar yazılan sorun örneklerine çözüm yolu üretmişlerdir. Fakat akran değerlendirme formları incelendiğinde iki grubun bu sorunlara olumlu çözüm yolu üretmedikleri görülmektedir. Genel olarak bakıldığında ise öğrencilerin amaçlara ulaşmada bir zorlukla karşılaşabileceklerini ve bu zorluklara çözüm yolları üretebilecekleri kazanımlarına ulaştıkları ortaya çıkmaktadır.

\section{Amaçlarını Gerçekleştirmiş Biri}

Amaçlarını gerçekleştirmiş biri konulu atölyede Walt Disney'in hayatı seçilmiş ve amaçlarına ulaşmada yaşadıkları ele alınmıştır. Öğrencilere bu atölyenin sonunda bir kâğıt verilerek Walt Disney'in amacına ulaşması ile ilgili öğrendikleri üç şeyi yazmaları istenmiştir. Öğrenciler bu kâğıtlara genel olarak Walt Disney'in "çalışkanlığı”, “zorluklar karşısında vazgeçmediği” ve "hayaller kurduğu” ile ilgili ifadeler yazmışlardır.

"Hayaller kurmuş ve kurduğu hayalleri takip etmiştir.", "Küçükken gazete satıyordu ama onun hayali karikatür sanatçısı olmaktı. Hayallerine ulaştı ve karikatür sanatçısı oldu.", "Walt Disney küçükken gazete satıyordu amaçlarına ulaştı ve zengin oldu.", "Walt Disney ailesi hasta olduğu için çok çalıştı.", "Çocukken çok çalıştı ve başarılı oldu."

Öğrencilerin verdiği bu ifadeler incelendiğinde, amaçlarına ulaşmış birinin hangi özelliklere sahip olduğu, amaçlarına ulaşmada neler yaşayıp neler yaptığı konusunda olumlu davranış kazandıkları görülmektedir.

\section{Genel Değerlendirme}

Genel değerlendirme atölyesinde öğrencilerle birer kukla yapılmış ve bu kuklalar aracılığıyla bütün sürecin değerlendirmesinin yapılabileceği etkinlikler uygulanmıştır. Öğrenciler süreç boyunca edindikleri amaç belirleme becerilerini kullanarak bu kuklaların belirledikleri amaçlar konusunda neler yapmaları gerektiğini ifade etmişlerdir. Sürecin en sonunda öğrencilerin kuklalarını amaçlarına ulaşma ve amaçlarını belirleme konusunda değerlendirmeleri için "Kukla Değerlendirme Formu" verilmiştir. Öğrenciler bu formda evet/hayır tipi sorularla kuklalarını değerlendirmiş, ayrıca formun en sonunda verilen açık uçlu soru ile onlara çeşitli önerilerde bulunmuşlardır. Evet / Hayır soruları bütün süreçte ele alınan kritik kazanımlarla ilgili olarak oluşturulmuştur. Öğrenciler çoğunluğu kuklalarının; 
İlkokul 4. Sınıf Öğrencilerinin Amaç Belirleme Becerilerinin Geliştirilmesi için Yaratıcı Drama Yönteminin Kullanılması

"Amaçlarını belirlerken hayal kurmaya önem verdiğini”, "Amaçlarını belirlerken yapabildiklerini ve yapamadıklarını belirlediğini”, "Bir tane amaç belirleyerek, birden çok amaç seçmediğini”, "Amaçlarına ulaşırken kendine bir plan ve yol haritası yaptı̆̆ını", "Amaçları konusunda kendini geliştirmeye önem verdiğini,

"Amaçlara ulaşma yolunda karşılaştığı zorluklar karşısında vazgeçmediğini," "Amaçlarına ulaşmak için çok çalıştığını, belirtmişlerdir.

Öğrencilerin kuklalarda bu özellikleri belirlemeleri, onların programın genel kapsamındaki kazanımları önemli ölçüde edindiklerini ortaya koymaktadır. Ayrıca öğrenciler kuklalarına verdikleri tavsiyelerde şunları belirtmişlerdir;

"Çok çalışması gerekir. Plan yapması gerekir. Kendini geliştirmeli ve zorlukları çizim yaparak geçmelidir. "Plan yapması, amacını anlatan görseller çizmesi, çok çalışmalı amaçlarından vazgeçmemelidir.", "Kendisine güvenmeli ve plan yapmalıdır. Gezegenler konusunda bilgi toplamalı ve kendini geliştirmelidir.", "Doktor olmak için iyice çalışmalı, iyi bir plan yapmalı ve amaç haritası yapmal, bir zorluk karşlsında pes etmemeli, kendine birini örnek almall."

Öğrencilerin özellikle "amaçlar konusunda çok çalışma", "kendisini geliştirme”, "plan yapma" ve "vazgeçmeme" gibi becerileri diğer beceri alanlarına göre daha çok vurguladıkları ortaya çıkmaktadır. Bu açıdan bakıldığında, bu beceriler amaç belirleme ve belirlenen amaca ulaşma sürecinin temel becerilerini oluşturmaktadır.

Projenin son atölyesi olan değerlendirme atölyesinde, öğrencilere oluşturdukları kuklaların bundan sonra amaçlarını belirleme konusunda nelere dikkat edecekleri sorulmuştur. Öğrencilerin kuklalar aracılığıyla verdiği yanıtlardan ortaya çıkan kelime ve kavramlara içerik analizi yapılarak ulaşılan kodlar çalışmanın kazanımlarına yönelik olarak kategorize edilmiş ve aralarındaki ilişki belirlenmiştir.

Tablo 2. Öğrenci Iffadelerine göre Kuklaların Amaçlarını Belirleme Konusunda Bundan Sonra Dikkat Etmeleri Gerekenlere İlişkin Verilerin Kategorik Olarak Sinıflandırılması

\begin{tabular}{|c|c|c|}
\hline Kategori & Kod & f \\
\hline \multirow[t]{2}{*}{ Çalışmak } & Bundan sonra amaçlarıma ulaşmak için çok çalışacağım. & 16 \\
\hline & Zorlukları çalışarak yeneceğim. & 5 \\
\hline \multirow[t]{2}{*}{ Kendine Uygun Amaçlar } & Yeteneklerime uygun amaçlar belirleyeceğim. & 11 \\
\hline & Kendime uygun amaç belirleyeceğim. & 8 \\
\hline \multirow[t]{3}{*}{ Vazgeçmemek } & Karşılaştı̆̆ım zorluklar kaşında vazgeçmeyeceğim. & 13 \\
\hline & Hemen amacımı bırakmayacağım. & 5 \\
\hline & Bir problem çıktı̆̆ında pes etmeyeceğim. & 4 \\
\hline \multirow[t]{2}{*}{ Seçim Yapmak } & Amaçlarım içinden bir seçim yapacağım. & 14 \\
\hline & Tek bir amaç seçip onda başarılı olacă̆ım. & 7 \\
\hline \multirow[t]{2}{*}{ Plan Yapmak } & Planlı olacă̆ım. & 12 \\
\hline & Amaçlarıma ulaşmak için plan yapacağım. & 10 \\
\hline \multirow[t]{2}{*}{ Kendini Geliştirmek } & Kendimi geliştireceğim. & 8 \\
\hline & Amaçlarım için kendimi geliştireceğim. & 2 \\
\hline \multirow[t]{2}{*}{ Görselleştirmek } & Amaçlarımı çizeceğim. & 6 \\
\hline & Hayallerimi görselleştireceğim. & 1 \\
\hline \multirow[t]{2}{*}{ Model Almak } & Birini örnek alacă̆ım. & 7 \\
\hline & Kendime başarılı olmuş birini seçeceğim. & 2 \\
\hline
\end{tabular}


Yukarıdaki içerik analizine bakıldığında ortaya çıkan temalar "çalışmak”, "kendine uygun amaçlar", "vazgeçmemek", "seçim yapmak", "plan yapmak", "kendini geliştirmek”, "görselleştirmek”, "model almak", şeklinde oluşturulmuştur. Tablodaki kodlar ve bu kodlarla ifade edilen katılımcı sayısına bakıldığında öğrencilerin en çok amaçlar konusunda çok çalışmak gerektiğini vurguladıkları ortaya çıkmıştır.

\section{Sonuç ve Öneriler}

İlkokul 4. sınıf öğrencilerinin amaç belirleme becerilerini geliştirmek için yaratıcı drama yöntemi ile oluşturulan öğrenme yaşantısı karma yöntem doğrultusunda değerlendiğinde, nicel ve nitel verilerin birbiri ile tutarlı olduğu ve öğrencilerde amaç belirleme becerilerinin olumlu yönde geliştiği ortaya çıkmıştır. Proje değerlendirmesinin nicel boyutunda uygulanan kazanım değerlendirme sınavının ön test ve son test sonuçlarının, toplam katılımcıların aldığı puanlar bazında pozitif yönde anlamlı sonuçlar ortaya çıkardığı görülmüştür. Bu sonuçlar, öğrencilerin amaç belirleme beceri alanının kazanımlarını büyük ölçüde edindiklerini ortaya koymaktadır.

Çalışmasının nitel veri analizinde; her atölye sonunda yapılan ölçme değerlendirme etkinliklerinin, formların ve öğrenci ürünlerinin analizi yapılmıştır. Bu analiz sonuçları atölye ve kritik kazanımlar doğrultusunda değerlendirildiğinde, öğrencilerin yazınsal ve sözlü ifadeleri atölye bazında oluşturulan kazanımları edindikleri yönündedir. Ayrıca son atölyede yapılan odak grup görüşmesi sonucunda ortaya çıkan kategoriler ve öğrenci ifadeleri, programın oluşturulmasında belirlenen hedefe ulaşıldığını ortaya koymaktadır. Programın karma yönteme göre değerlendirilmesi, ortaya çıkan verilerin programın amacına ulaştığı yöndeki pozitif göstergesi ve verilerin birbirleri ile olan anlamlı ilişkisi ortaya çıkan sonuçların güvenirliğini arttıracak niteliktedir.

Tüm bu bulgulara dayalı olarak İlkokul 4. sınıf öğrencilerinin amaç belirleme becerilerini geliştirmek için yaratıcı drama yöntemini kullanarak oluşturulan öğrenme yaşantısının başarılı olduğunu söylenebilir. Bu açıdan bakıldığında çalışma, öğrencilerin duygusal zekâ, sosyal ve kişisel gelişimi için oluşturulan diğer yaratıcı drama yönteminin kullanıldığı öğrenme yaşantılarıyla yakın sonuçlar vermektedir (Wright, 2006; White, 2007; Ceylan, 2009).

Hayat Bilgisi Öğretim Programı'nda 2006'dan sonra yer alan öz yönetim becerilerinin öğrencinin nitelikli bir yaşam sürmesi açısından öneminin büyük olduğu ortadadır. Özellikle öz yönetim becerilerinin en önemli alt alanlarından biri olan "amaç belirleme becerisi" bireyin kendi istediği bir yaşamı idame ettirebilmesi ve kendi öz iradesi ile belirlediği amaçlara, hedeflere ulaşmasını sağlayan bir yaşam becerisi olmaktadır. Öğrencilerin bireyselleşmeleri, hem kendi amaçlarını ve kendilerini tanımaları hem de amaçlarını kendileri belirleyerek hedeflerine ulaşmaları, bireysel olarak kendilerini ve içinde bulundukları toplumu geliştirecek, ilerletecek önemli bir unsurdur. Bu açıdan bakıldığında öz yönetim ve amaç belirleme gibi alt becerileri bireylere eğitim yoluyla kazandırmak için ilk önce eğitimin temel taşı olan eğitim programlarında yani öğrencilere sunulan yaşantılar düzeneğinde gereken önemin verilmesi gerekmektedir. Bunun için de bu çalışmada yapıldığı gibi yaşam becerilerini yaşantısal yollarla kazandırmada etkili bir yöntem olan yaratıcı dramanın öğrenmeöğretme süreçlerinde kullanıldığı öğretim programları hazırlanmalıdır. Oluşturulan programlar, temel derslerden ayrı tutularak profesyonel yaratıcı drama liderleri tarafindan uygulamaya geçirilmeli ve sürekli değerlendirmeler yapılarak programların öğrencide bu yaşam becerilerini kazandırmadaki işlevselliği sınanmalıdır. 
İlkokul 4. Sınıf Öğrencilerinin Amaç Belirleme Becerilerinin Geliştirilmesi için Yaratıcı Drama Yönteminin Kullanılması

\section{Kaynakça}

Adıgüzel, Ö. H. (2006). Yaşantılara dayalı öğrenme yaratıcı drama ve süreçsel drama ilişkileri. Yaratıcı Drama Dergisi, 1(1), 31-38.

Adıgüzel, Ö. H. (2006). Yaratııı drama kavramı, bileşenleri ve aşamaları. Yaratıcı Drama Dergisi, 1(1), 17-30.

Adıgüzel, Ö.H. (2012). Eğitimde yaratıcı drama.(2.Baskı) Ankara: Naturel Yayıncılık

Balc1, A. (2011). Sosyal bilimlerde araştırma. Ankara: Pegem A Yayıncılık.

Boyatzis, E, Richard. Sala Fabio (ed. GleenGeher) (2004). The measurement of emotional intelligence: common ground and controversy. Hauppauge, NY: Nova Sience Publishers.

Bozdoğan, Z. (2006). Okulda rehberlik etkinlikleri ve yaratıcı drama. Ankara: Nobel Yayıncılık.

Can, A. (2013). SPSS ile nicel veri analizi. Ankara: Pegem A Yayıncılık.

Ceylan, Ş. (2009). Vineland sosyal- duygusal erken çocukluk ölçeğinin geçerlik-güvenirlik çalışması ve okul öncesi eğitim kurumuna devam eden beş yaş çocuklarının sosyal-duygusal davranıșlarına yaratıcı drama eğitiminin etkisinin incelenmesi. Yayınlamış doktora tezi. Gazi Üniversitesi, Ankara.

Cingisiz, N., Murat, M. (2010). Evlenmek için birbirlerini tercih eden çiftlerin duygusal zeka düzeylerinin bazı değişkenler açısından incelenmesi. Gazi Antep Sosyal Bilimler Dergisi, 9(1), 99-114.

Cohen, J.(Ed.)(1999). Educating mindsand hearts: social emotional learning and the passage intoadolescene. New York: Teachers College Press.

EPÖ Profesörler Kurulu (2005) Yeni İlköğretim Programını Değerlendirme Toplantısı Sonuç Bildirisi. http:// ilkogretimonline. org.tr/vol5say1/bildirge 2005

Goleman, D. (2011). Duygusal zeka neden IQ'dan daha önemli? (Çev. Banu Seçkin Yüksel). İstanbul: Varlık/ Bilim.

Kabapınar, Y. (2009). İlköğretimde hayat bilgisi ve sosyal bilgiler eğitimi. Ankara: Maya Yayıncılık.

MEB (2009). İlköğretim hayat bilgisi dersi ögretim programı ve kılavuzu (1. 2. 3. sinıflar) http://ttkb.meb.gov. tr/program2.aspx?islem=1\&kno=30 (Erişim Tarihi:10.01.2013)

Karaca, K. ve Ocak, G. (2011). Hayat bilgisi ders kitaplarının becerilere uygunluk düzeylerinin öğretmen görüşlerine göre değerlendirilmesi (Afyonkarahisarlı örneklemi). Kuramsal Eğitimbilim 4(1), 108-125

Salovey, P., Mayer, J. D. (1990). Emotional intelligence. Imagination, Cognition, and Personality, 9, 185-211.

Salovey, P., Mayer, J. D., \&Caruso, D. (2002). The positive psychology of emotional intelligence. In C. R. Snyder\& S. J. Lopez (Eds.), Hand book of positive psychology (pp. 159 -171). London: Oxford University Press.

Schiling, D. (2009). Duygusal zeka becerileri eğitimi uygulamaya yönelik pratik bir model ve "50 aktivite". Ankara: Maya Akademi.

Üstündağ, T. (1994). Günümüz eğitiminde dramanın yeri. Yaşadıkça Eğitim Dergisi, 37, 7-10.

Yıldırım, A ve Şimşek H. (2011). Sosyal bilimlerde nitel araştırma yöntemleri. Ankara: Seçkin Yayıncılık.

Wright, R. P. (2006). Drama education and development of self: Mythorreality?. Social Psychology of Education, 9, 43-60.

White, C. I. (2007). Self study examining the effectiveness of creative dramatics with urban youth. Unpublished doctorate dissertation. University of Maryland, Baltimore. 


\section{Ek-1: Atölye Planı Örneği}

$\begin{array}{ll}\text { Konu } & \text { : Amaçların Arasından Bir Seçim } \\ \text { Grup } & \text { : Okçu Musa İlkokulu 4-B sınıfı öğrencileri } 16 \text { kişi (11 Erkek, 5 Kız) } \\ \text { Süre } & : 80 \text { dakika }(40+40) \\ \text { Yöntem } & \text { : Yaratıcı Drama } \\ \text { Teknikler } & \text { : Rol oynama, doğaçlama } \\ \text { Araç / Gereç } & : \text { : } 3 \text { adet kırmızı zarf, } 3 \text { adet sarı zarf, 3 adet beyaz renkte zarf, } 16 \text { adet Kağan'ın } \\ \text { u, patafix, } 4 \text { adet A4 kağıdı, } 4 \text { adet 12'li pastel boya, postit kağıtları }\end{array}$

\section{Kazanımlar:}

- Ulaşmak istediği amaçlar arasından bir seçim yapmanın gerekliliğini fark eder.

- Amaçları arasından kendi yetenek ve ilgilerine uygun bir seçim yapar.

- Canlandırma hazırlanırken arkadaşları ile işbirliği yapar.

\section{Süreç:}

\section{A. Hazırlık / Isınma}

\section{Etkinlik 1}

Bütün katılımcılar alanın ortasında birbirlerine çok yakın bir şekilde beklerler. Lider katılımcıların bulunduğu noktanın olabildiğince uzağına ve birbirinden farklı yerlere, beş iple oluşturulmuş çember yerleştirir. Lider "Çocuklar birazdan ben yönerge verdiğimde hepiniz seçtiğiniz bir çemberlerin içine girmeye çalışacaksınız. Fakat bir çemberin içine sadece iki kişi girebilir. Dışarda kalan kişiler oyun dışı kalacaktır.” der. Lider etkinliği 2-3 tur uygular ve oyunda kalan katılımcı sayısına göre ipten oluşturulan çemberlerin sayısı eksiltilir. En sona kalan katılımcılar bütün grup tarafindan tebrik edilir. Daha sonra lider bu oyunda başarılı olmak için neler yapılması gerektiğini sorgular.

\section{Etkinlik 2}

Lider katılımcıları üç gruba ayırır. Her gruba sarı, kırmızı ve mavi olmak üzere üç farklı renkte zarf verir. Lider " Birazdan bir grubu dışarıya alacağız, içeride kalan grup ilk olarak mavi renkte olan zarfı saklayacak. Daha sonra diğer grup geldiğinde saklanan mavi zarfı bulmaya çalışacak. Zarfları bulmaya çalışan grubun, diğer gruptan ipucu isteme hakkı var. İpucu sıcak mı?, soğuk mu? sorusu ile istenilecek. Eğer grup zarfa yakın bir yerde olursa sıcak denilecek, eğer zarfa uzak bir yerde olursa soğuk denilecek.” der. Lider ayrıca iki grubun bütün zarflara ulaşmak için aynı çalışmayı yapacağını ve süreç sonunda en az ipucu isteyerek zarflarının hepsine ulaşan grubun kazanacağını belirtir. İlk olarak gönüllü bir grup dışarıya alınır ve etkinlik başlatılır. Grup saklanan zarfa ulaştığında, diğer grup dışarıya alınır. Bu şekilde bütün gruplar üç renkte zarfa da ulaştıklarında etkinlik tamamlanır. Daha sonra grupların ipucu isteme sayıları toplanarak karşılaştııılır ve en az ipucu alarak, tüm zarflarına ulaşan grup tebrik edilir.

Mavi renkli zarfta: "Merhaba Arkadaşlar,

Benim adım Kağan ve on bir yaşında dördüncü sınıf öğrencisiyim. Uzun zamandır hayaller âlemine dalıyorum ve gelecekte nasıl biri olacağımı, nasıl bir yaşama sahip olacağımı düşünüp duruyorum. Ve bunun için kendime bazı amaçlar belirlemeye çalışıyorum. Bazen tüm bunları düşünmek için çok zaman harcıyorum.”

Kırmızı renkli zarfta: "Hayallerime ulaşmak için amaçlarımı belirleme konusunda bazen çok zorluk çekiyorum. Çünkü geleceğim hakkında düşlediğim bu hayallerden gerçekten hangilerinin benim için uygun olduğuna karar verebilmiş değilim. Resim yapmayı, kısa öyküler yazmayı, bilgisayarla vakit geçirmeyi, tiyatro etkinliklerini, bilimsel çocuk dergileri okumayı, okul gezilerine katılmayı, macera filmleri izlemeyi ve bahçe işlerinde babama yardımcı olmayı çok seviyorum. Gelecekteki yaşamımda bunlarla ilgili bir şeyler yapmak isterdim." 
Sarı renkli zarfta: “Amaçlarımı belirledikten sonra ise onlara nasıl ulaşabileceğimi düşünemem lazım. Amaçlarıma ulaşma yolunda beni nelerin beklediğini, nasıl bir yol belirlemem gerektiğini ve kendimi nasıl hazırlamam gerektiğini bilmiyorum. Sizden istediğim bana bu konularda yardımcı olmanız ve tavsiyelerde bulunmanız. Tüm tavsiyeleriniz için şimdiden teşekkür ederim.” yazılıdır.

Lider gruplara zarfların içinde, bir mektubun üç parçaya bölünmüş halinin bulunduğunu söyler. Gruplar kendi zarflarının içinden çıkan mektup parçalarını bir araya getirerek mektubu okurlar. Lider bütün katılımcılara mektubun kimden geldiğine, nasıl bir içeriğinin olduğuna dair sorular sorar. Cevap vermek isteyen katılımcılara söz hakkı verilir.

Ara Değerlendirme: Lider “ Çocuklar sizce bu mektubu yazan kişi nasıll bir duygu durumu ile bu mektubu yazmış olabilir?” sorusunu yöneltir. Katılımcılarla bu soru derinleştirilerek sorgulanır.

\section{B. Canlandirma}

\section{Etkinlik 4}

Lider önceden hazırlanan dört adet kraft kâğıdını alanın farklı yerlerine koyar. 1.kraft kâğıdının üzerinde "Burada herkes birbirlerine yetenekli olduğu alanlardan bahseder." 2.kraft kâğıdının üzerinde "Burada herkes birbirlerine yapmaktan hoşlandığı şeylerden bahseder." 3.kraft kâğıdının üzerinde "Burada herkes yetenekli olduğu alanlarla ilgili hayallerinden bahseder" 4.kraft kâğıdının üzerinde " Burada herkes yetenek ve ilgilerinin olduğu alanlarla ilgili belirledikleri amaçlardan bahseder."

Lider katılımcılara yerde olan kraf kâğıtlarının hepsinin üzerinde yazan yönergeleri okumalarını belirtir. Daha sonra lider katılımcılara kendilerini Kağan'ın yerine koymalarını ve Kağan'ın yapmaktan hoşlandığı alanlardan birini seçmelerini söyler. Lider "Çocuklar birazdan alan içerisinde serbest bir şekilde yürümeye başlayacağız. Ben yönerge verdiğimde herkes en yakınındaki kraft kâğıdının üzerine çıkacak. Her bir kraft kâğıdının üzerinde sadece 3 kişi olabilir. Çıktığınız kraft kâğıdının üzerinde ne yazıyorsa kendinizi Kağan'ın yerine koyarak, belirlediğiniz ilgi alanları konusunda, kraft kâğıdının üzerinde olan diğer arkadaşlarınızla paylaşımda bulunuyorsunuz." der. Katılımcılar liderin verdiği yönergeye uygun olarak çalışmayı yaparlar. Daha sonra lider tekrar katılımcılara alan içerisinde serbest bir şekilde dolaşmalarını söyler. Lider yönerge verdiğinde bu sefer katılımcılar daha önce üzerine çıkmadıkları bir kraft kâğıdına çıkarak kraft kâğıdında yazılı olan yönergeye uygun paylaşımda bulunurlar. Bütün katılımcılar her seferinde daha önce üstüne çıkmadıkları bir kraft kâğıdının üzerine çıkarlar. Katılımcıların hepsi dört kraft kâğıdından dördünün de üzerine çıkıp Kağan rolünde kendi seçtiği ilgi ve yetenek alanları ile ilgili paylaşımda bulunduğunda etkinlik sonra erer.

\section{Etkinlik 5}

Lider katılımcıları üç gruba ayırır. Her gruba bir dramatik durum örneği verir. Dramatik durumlar:

1.Gruba verilen dramatik durum örneği; Kağan'ın bulunduğu sınıfta sosyal etkinlik kulüp seçimleri yapılmaktadır. Öğretmen bütün öğrencilerin istek ve ilgileri doğrultusunda sosyal etkinlik kulüplerine kaydını yapar. Bütün öğrenciler sıra ile yer almak istedikleri kulüp etkinliklerinden birini söyler. Kağan'a sıra geldiğinde neredeyse bütün kulüplerin ismini sayarak, bu kulüplerde yer almak istediğini belirtir. Öğretmen ve öğrenciler Kağan'ın bu isteğine tepki gösterirler.

2. Gruba verilen dramatik durum örneği; Kağan'ın ailesi, Kağan'ın okul dışı boş zamanlarını verimli bir şekilde değerlendirebilmesi için onu bir sosyal etkinliğe göndermeye karar verirler. Babası Kağan için seçebileceği etkinliklerin listesini çıkarmıştır. Bu listede birçok farklı sosyal etkinlik yer almaktadır. Kağan'a ailesi hangisine gitmek istediğini sorduğunda Kağan hepsine gitmek istediğini ve hepsine karşı ilgisinin olduğunu belirtirek bu konuda ısrarcı davranır. Ailesi Kağan'ı sadece bir etkinlik seçmesi konusunda ikna etmeye çalışırlar.

3. Gruba verilen dramatik durum örneği; Öğretmen Kağan ve arkadaşlarından bir çalışma grubu oluşturarak herhangi bir dersle ilgili proje konusu belirlemelerini ister. Çalışma grubundaki bütün öğrenciler bir araya gelerek proje için çalışmak istedikleri ders konusunda bir öneri söylerler. Kağan'a sıra geldiğinde neredeyse bütün ders alanlarında çalışmak istediğini belirterek bunun gerekli ve önemli olduğu konusunda ısrarcı davranır. Grup arkadaşları böyle bir seçim yaptıklarında asla başarılı olamayacaklarını düşünürler. 
Lider grupların canlandırmalarını hazırlamaları belirli bir süre verir. Bütün gruplar hazır olduğunda ilk gruptan başlayarak sıra ile grupların canlandırmaları izlenir. Her grubun canlandırmasının sonunda gruplara diğer katılımcılar tarafından çeşitli geri bildirimler verilir.

\section{Değerlendirme:}

\section{Etkinlik 6}

Lider katılımcıların hepsine Kağan'ın mektubunu dağıtır. Bütün katılımcılar mektubu tekrar okuyup Kağan'a, istediği önerilerin ve tavsiyelerin bulunduğu bir mektup yazarlar. Lider yazılan mektupları toplayarak atölyeyi sona erdirir.

\section{Etkinlik 7}

Katılımcılar çember biçiminde oturur. Lider öğrencilerin bütün süreci yansıtmaları için "Bugün yapılan etkinliklerin sonunda kendinizi nasıl hissediyorsunuz? " Bugün önemli olduğunu fark ettiğiniz veya öğrendiğiniz neler var?” şeklinde sorular. Bütün katılımcılardan en az bir cümlelik yanıt alındığında etkinlik tamamlanır. 